\title{
Duração razoável do processo: análise de seus pressupostos e contribuição para definição de parâmetros objetivos
}

\section{Reasonable duration of process: an analysis of Its assumptivos and a contribution to setting objectives parameters}

\section{Resumo}

O direito a julgamento de prazo razoável é tema de bastante importante e também carente de uma definição precisa. Muito embora esse direito, atualmente, alcance todos os processos, o presente artigo buscará analisar o referido direito especialmente nos processos de natureza criminal, bem como oferecer uma contribuição para o debate do tema, partindo das ideias de Aury Lopes Júnior.

Palavras-chave: Processo penal. Prazo. Razoabilidade. Definição.

\begin{abstract}
The right to trial within a reasonable time is a very important topic and also lacks a precise definition. Although this right currently reach all processes, this article will seek to examine that right especially in the prosecution of criminal activity, as well as make a contribution to the discussion of the topic, based on the ideas of Aury Junior Lopes.
\end{abstract}

Keywords: Criminal Procedure. Deadline. Reasonableness. Definition. 


\section{Introdução}

O direito a julgamento de prazo razoável é tema importante e também carente de uma definição precisa. Muito embora esse direito, atualmente, alcance todos os processos, o presente artigo buscará analisar o referido direito especialmente nos processos de natureza criminal. No âmbito do processo penal, esse tema já vem sendo trabalhado por diversos autores, mas em especial pelos Professores Aury Lopes Júnior e Gustavo Badaró ${ }^{2}$, que dedicaram importante artigo a respeito desse tema. Assim, o presente artigo buscará expor brevemente as suas ideias, analisar a sua viabilidade de sua admissão pelos Tribunais Superiores, bem como oferecer uma contribuição para o debate do tema.

\section{Fundamentos}

Os fundamentos para o julgamento em prazo razoável remontam a Declaração Universal dos Direitos do Homem e Cidadão (1948). Ainda no âmbito internacional, há a previsão na Convenção Europeia para Proteção de Direitos Humanos e das Liberdades ${ }^{3}$, bem como o próprio Pacto de San Jose da Costa Rica ${ }^{4}$.

LOPES JUNIOR, Aury; BADARÓ, Gustavo Henrique. Direito ao processo penal no prazo razoável. Rio de Janeiro: Lúmen Júris, 2006.

3 "Art. $6^{\circ}, \S 1^{\circ}$ : Toda pessoa tem o direito a que sua causa seja ouvida com justiça, publicamente, e dentro de um prazo razoável por um Tribunal independente e imparcial estabelecido pela Lei, que decidirá sobre os litígios, sobre seus direitos e obrigações de caráter civil ou sobre o fundamento de qualquer acusação em matéria penal dirigida contra ela." "Art. $5^{\circ}, \S 3^{\circ}$ : Toda a pessoa presa ou detida nas condições previstas no parágrafo $1^{\circ}, \mathrm{c}$, do presente artigo, deve ser trazida prontamente perante um juiz ou um outro magistrado autorizado pela lei a exercer a função judiciária, e tem o direito de ser julgado em um prazo razoável ou de ser posto em liberdade durante a instrução. O desencarceiramento pode ser subordinado a uma garantia que assegure o comparecimento da pessoa à audiência."

$4 \quad$ Art. 7 parágrafo 5. Toda pessoa presa, detida ou retida deve ser conduzida, sem demora, à presença de um juiz ou outra autoridade autorizada por lei a exercer funções judiciais e tem o direito de ser julgada em prazo razoável ou de ser posta em liberdade, sem prejuízo de que prossiga o processo. Sua liberdade pode ser condicionada a garantias que assegurem o seu comparecimento em juízo. Artigo 8, parágrafo 1: Toda pessoa terá o direito de ser ouvida, com as devidas garantias e dentro de um prazo razoável, por um juiz ou Tribunal competente, independente e imparcial, estabelecido anteriormente por lei, na apuração de qualquer acusação penal formulada contra ela, ou na determinação de seus direitos e obrigações de caráter civil, trabalhista, fiscal ou de qualquer outra natureza.
No mesmo sentido, as disposições constantes no Pacto Internacional sobre Direitos Civis e Políticos, adotado pela Assembleia Geral das Nações Unidas ${ }^{5}$ :

No ordenamento jurídico pátrio, o artigo $5^{\circ}$, inciso LXXVIII, da Constituição Brasileira trazido pela EC 45/2004 estabeleceu a garantia individual do julgamento prazo razoável: [...] a todos, no âmbito judicial e administrativo, são assegurados a razoável duração do processo e os meios que garantam a celeridade de sua tramitação.

\section{Algumas observações preliminares}

Deve-se, desde já, registrar-se que o direito à duração razoável do processo tem o inconveniente de lidar com dois conceitos indeterminados, quais sejam, a própria definição ou convenção do termo tempo, bem como duração razoável.

Não se pode deixar de destacar alguns pontos, como a necessidade de equilíbrio entre a morosidade do processo tipo tartaruga e a aceleração indevida do processo lebre, segundo palavras do próprio Aury Lopes Júnior, pois se a demora do processo pode ser considerada uma punição autônoma e ilegítima, a aceleração antigarantista impede a garantia de direitos fundamentais ${ }^{6}$.

Além disso, também não se pode deixar de mencionar que há por parte da acusação o direito legítimo de acusar aqueles que preenchem os requisitos legais para a denúncia.

Ademais, discussão a respeito da duração razoável do processo penal ainda tem uma repercussão ainda maior quando se trata de réu que está submetido à prisão preventiva ou outra medida cautelar agora trazida pela Lei 12.403/2011, que estabeleceu para o Direito Penal uma série de medidas cautelares diversas da prisão preventiva.

Definir um parâmetro objetivo para duração da

\footnotetext{
"Art. 9, $\mathrm{n}^{\circ}$ 1: Qualquer pessoa, presa ou encarcerada em virtude de infração penal, deverá ser conduzida, sem demora, à presença do juiz ou outra autoridade habilitada por lei a exercer as funções judiciais e terá o direito de ser julgada em prazo razoável ou de ser posta em liberdade. A prisão preventiva de pessoas que aguardam julgamento não deverá constituir regra geral, mas a soltura poderá estar condicionada a garantias que assegurem o comparecimento da pessoa em questão à audiência, a todos os atos do processo e, se necessário for, à execução da sentença."

6 LOPES JUNIOR, Aury; BADARÓ, Gustavo Henrique. Direito ao processo penal no prazo razoável. Rio de Janeiro: Lúmen Júris, 2006. p. 40.
} 
prisão e do próprio processo é um grande desafio e é o que se pretende sugerir ao final.

\section{0 tempo e o processo}

De plano, deve-se tecer algumas considerações em relação ao primeiro dos termos imprecisos para a interpretação do direito à razoável duração do processo, qual seja, o tempo.

Recorrendo-se ao Dicionário de Filosofia, encontrou-se ao menos três concepções fundamentais para o conceito de tempo: 1) Tempo como ordem mensurável do movimento; 2) Tempo como movimento intuído; e 3) Tempo como estrutura de possibilidades?

A primeira concepção, sem dúvida alguma, é a mais difundida, pois pressupõe uma ordem e uma uniformidade, sem relação com nada externo, ou seja, é o tempo do calendário. Einstein e sua teoria da relatividade, por sua vez, não inovaram no conceito tradicional de ordem de sucessão, mas negaram que a ordem de sucessão fosse única e absoluta, uma vez que dois eventos simultâneos para determinado sistema de referência, poderiam não ser simultâneos para outro sistema de referência ${ }^{8}$.

Já a concepção de tempo como intuição do movimento ou de dever intuído, atribuída a Hegel, reduz o tempo à consciência. Diferencia-se da primeira concepção uma vez que o tempo da ciência é espacionalizado, representado por uma linha imóvel, todavia, o tempo, para essa concepção, seria móvel, num processo contínuo de criação9.

Por fim, a terceira concepção, desenvolvida por Heidegger a obra Ser e o Tempo, transforma o tempo em uma estrutura de possibilidades, estabelecendo entre os eventos do passado, presente e futuro, não uma relação de necessidade, mas de possibilidade, o que auxiliaria na explicação da teoria da relatividade de Einstein. O tempo seria considerado como um círculo, "em que aquilo de que se tem perspectiva no futuro é aquilo que já foi; por sua vez, o que já foi é aquilo de que se tem perspectiva para o futuro ${ }^{10 "}$.

ABBAGNANO, Nicola. Dicionário de filosofia. Edição revista e ampliada. São Paulo: M. Fontes. 2007.

8 ABbagnano, Nicola. Dicionário de filosofia. Edição revista e ampliada. São Paulo: M. Fontes, 2007. p. 1117.

9 ABBAGNANO, Nicola. Dicionário de filosofia. Edição revista e ampliada. São Paulo: M. Fontes, 2007. p. 1116.

10 ABBAGnANO, Nicola. Dicionário de filosofia. Edição revista e ampliada. São Paulo: M. Fontes, 2007. p. 1116.
É claro que diante dos limites do presente artigo e principalmente pelos limites do Autor, não se pretende instaurar um debate filosófico a respeito do conceito de tempo. Busca-se apenas indicar que uma concepção linear e absoluta de tempo não é o único critério existente. Além disso, como se verá abaixo, muito da discussão a respeito da razoabilidade ou não do tempo do processo ou de prisão de um acusado apenas concretizam o debate filosófico a respeito do conceito de tempo.

Aury Lopes Júnior e Gustavo Badaró, da mesma forma, iniciam sua reflexão no texto mencionado expondo brevemente a concepção filosófica do tempo ${ }^{11}$. No texto, eles informam, como maior propriedade, a dicotomia existente entre a concepção linear e relativa de tempo ${ }^{12}$.

O conceito linear de tempo, baseado nas ideias de Isaac Newton, é o tempo contado a partir do calendário, contados em dias, meses e anos, critério adotado pelo Direito Penal para a definição das penas mínima e máxima. Em Newton, o tempo é linear, absoluto e universal. Ao lado desse conceito, tem-se aquele baseado na teoria da relatividade de Einstein, no qual o tempo se relativiza, ou seja, tempo seria a medição do movimento, mas também dependeria da posição do observador ou do sistema de referência eleito ${ }^{13}$.

Transferindo essa apreensão para o direito, pode-se concluir, sem muita dificuldade, que o tempo fora da prisão ou sem estar submetido a um processo penal correria de maneira mais rápida que o tempo na prisão. Com isso, os autores propõem que a execução da pena e o próprio processo deveriam trabalham com o conceito de tempo baseado na teoria da relatividade de Einstein.

Não que isso tenha sido uma intenção deliberada do legislador, mas a concepção relativa de tempo já parece influenciar a execução da pena, tendo em vista o sistema progressivo de cumprimento de pena. Afinal, o sistema eleito pelo Código Penal admite a progressão de regime com o cumprimento parcial da reprimenda. Fosse o tempo considerado linear e absoluto, talvez o sistema progressivo não fosse admitido.

11 LOPES JUNIOR., Aury; BADARÓ, Gustavo Henrique. Direito ao processo penal no prazo razoável. Rio de Janeiro: Lúmen Júris, 2006.

12 LOPES JUNIOR., Aury; BADARÓ, Gustavo Henrique. Direito ao processo penal no prazo razoável. Rio de Janeiro: Lúmen Júris, 2006.

13 LOPES JUNIOR., Aury; BADARÓ, Gustavo Henrique. Direito ao processo penal no prazo razoável. Rio de Janeiro: Lúmen Júris, 2006. 
Por outro lado, os críticos do sistema progressivo - especialmente o senso comum - podem ser enquadrados entre aqueles que defendem um conceito absoluto de tempo, ou seja, consideram os 10 anos de pena a que foram condenados o réu, da mesma forma que os 10 anos fora da prisão.

Ademais, aliado à natureza absoluta de tempo, tem-se que muitos dos que defendem o cumprimento de determinada pena em regime exclusivamente fechado como era a redação inicial da lei dos crimes hediondos - podem ainda ser enquadrados na terceira concepção de tempo, aquela que o define como uma estrutura de possibilidades, em que "o que já foi é aquilo de que se tem perspectiva para o futuro." Ou seja, como no passado o réu cometera um crime hediondo, por exemplo, o que se pode esperar do futuro é que ele possa reincidir. Assim, quanto mais tempo ficar preso tanto melhor para a sociedade.

Ultrapassada minimamente a discussão filosófica a respeito do conceito de tempo e posicionando a sua discussão em relação ao cumprimento de uma pena privativa de liberdade, pode-se agora enfrentar a interpretação da duração razoável do processo.

\section{Do processo penal como forma de constran- gimento legal ou ilegal}

Submeter um réu a um processo, sem dúvida, pode ser considerado uma forma de constrangimento, constrangimento que se dá de maneira legítima caso hajam indícios concretos para a acusação. Ocorre que esse constrangimento, inicialmente, legal, pode se tornar ilegal, caso o processo ou a prisão processual ultrapassem o tempo considerado razoável.

Dentre os constrangimentos que um processo em curso pode gerar para o acusado, podem-se destacar: Óbice ou algum tipo constrangimento à participação em concurso público ${ }^{14}$, especialmente naqueles que preveem

14 Muito embora a questão esteja relativamente pacificada no STF (REs 424855 e 559135), quando a impossibilidade de se impedir a participação em concurso público daquele que tenha contra si processo penal em curso, não é incomum que a exigência de "nada consta" criminal seja exigido em editais de determinados concurso públicos. prova oral ${ }^{15}$ ou a contratação na esfera privada ${ }^{16}$; Restrição à disponibilidade de bens em caso de decretação de cautelar com esse escopo; Estigmatização pela eventual exposição na mídia, com repercussões negativas para a família ${ }^{17}$; Risco concreto do processo em curso ser considerado como maus antecedentes ${ }^{18}$ ou mau comportamento social ${ }^{19}$;Óbice a aplicação do princípio da insignificância, como ocorrer no caso do crime de descaminho ${ }^{20}$.

Não indicando propriamente todas essas repercussões, os autores já citados entendem que a duração desarrazoada do processo ocasiona à ofensa aos princípios da jurisdicionalidade ${ }^{21}$, pois impõe pena sem sentença. Além disso, seria uma ofensa também à própria presunção de não-culpabilidade, à ampla defesa e ao contraditório. Indicam também, aqui sem a nossa concordância,

15 No caso da prova oral, como ela normalmente é a última fase do concurso, notadamente após a sindicância da vida pregressa, muito embora o processo penal em curso não seja óbice a aprovação, não há como negar a possibilidade dessa circunstância gerar uma indisposição nos examinadores.

16 Na esfera privada, os óbices a quem tem um processo penal em curso dificulta o acesso a determinadas funções.

17 Já há muito o tema processo penal e mídia vem instigando os doutrinadores da área penal, A ausência de uma política de divulgação por parte da polícia, Ministério Público e Judiciário podem levar a condenação antecipada dos acusados, especialmente, quando o julgamento se dá pelo tribunal do Júri.

18 Os processos penais em curso como configuradores ou não de maus antecedentes teve a repercussão geral reconhecida no Recurso Extraordinário 591.563. O Min. Ricardo Lewandowski, exemplificadamente, entende que os processos em curso podem sim ser considerados maus antecedentes.

19 Esse último, muito embora rechaçado nos tribunais, ainda se vê aplicado no âmbito da Justiça de primeira instância

20 A Turma indeferiu habeas corpus impetrado em favor de condenado pela prática do delito de descaminho $(\mathrm{CP}$, art. 334), no qual se pretendia o trancamento de ação penal, por atipicidade da conduta, com base na aplicação do princípio da insignificância, pois o tributo devido seria inferior a $\mathrm{R} \$ 10.000,00$. Considerou-se que, embora o tributo elidido totalizasse $\mathrm{R} \$ 8.965,29$, haveria a informação de que o paciente responderia a outro processo - como incurso no mesmo tipo penal - cujo valor não pago à Fazenda Pública, considerados ambos os delitos, seria de R $\$ 12.864,35$. Destacou-se estar-se diante de reiteração de conduta delitiva, pois o agente faria do descaminho seu meio de vida, daí a inaplicabilidade do referido postulado. O Min. Marco Aurélio, relator, enfatizou seu convencimento no sentido de que, sendo o montante superior a R\$100,00, caberia concluir-se pela tipicidade. HC 97257/RS, rel. Min. Marco Aurélio, 5.10.2010 (HC-97257).

21 LOPES JUNIOR, Aury; BADARÓ, Gustavo Henrique. Direito ao processo penal no prazo razoável. Rio de Janeiro: Lúmen Júris, 2006. p. 40. 
que a duração desarrazoada do processo levaria a perda de prestígio da tese da defesa ${ }^{22}$.

Diante disso, os autores propõem alguns critérios para a definição do prazo para julgamento em prazo razoável.

\section{Critérios atuais para definição de prazo razoável}

Predomina na jurisprudência do Supremo Tribunal Federal a doutrina do não-prazo fixo para duração da prisão processual ${ }^{23}$, não havendo manifestação específica em relação ao curso do processo em si.

Com base nessa posição, há algumas propostas para definição de parâmetros para definição do quem viria a ser prazo razoável.

Ao tempo da vigência do revogado procedimento comum ordinário, a doutrina defendia que o prazo razoável de duração do processo, estando o réu preso, seria de 81 dias para julgamento do processo. Esse parâmetro decorria da contagem dos prazos estabelecidos no Código de Processo Penal para quando o réu estava preso. Além disso, foi previsto expressamente no artigo $8^{\circ} \mathrm{da}$ Lei 9.034/95 - Lei das organizações criminosas ${ }^{24}$. Àquela época, contudo, essa visão não era pacífica e a jurisprudência estabelecia uma série de mitigações à obrigatoriedade desse prazo, com a edição das Súmulas 21, 52 e 64 do Superior Tribunal de Justiçąa ${ }^{25}$.

22 A discordância na hipótese fundamenta-se no fato de que o tempo pode levar ao próprio esquecimento do fato, um dos fundamentos da prescrição penal.

23 [...]. 1. O Supremo Tribunal Federal entende que a aferição de eventual excesso de prazo é de se dar em cada caso concreto, atento o julgador às peculiaridades do processo em que estiver oficiando. 2. No caso, a custódia instrumental dos pacientes já ultrapassa 7 (sete) anos, tempo superior até mesmo a algumas das penas do Código Penal. Prazo alongado esse que não é de ser debitado decisivamente à defesa. 3 . A gravidade da imputação não obsta o direito subjetivo à razoável duração do processo (inciso LXXVIII do art. $5^{\circ}$ da CF). 4. Ordem concedida. (HC 102668, Relator(a): Min. DIAS TOFFOLI, Primeira Turma, julgado em 05/10/2010, DJe-020 DIVULG 31-012011 PUBLIC 01-02-2011 EMENT VOL-02454-03, PP-00632).

24 Art. $8^{\circ} \mathrm{O}$ prazo para encerramento da instrução criminal, nos processos por crime de que trata esta Lei, será de 81 (oitenta e um) dias, quando o réu estiver preso, e de 120 (cento e vinte) dias, quando solto

25 ENCERRADA A INSTRUÇÃO CRIMINAL, FICA SU-
Com a mudança do procedimento comum ordinário, que alterou os prazos do procedimento comum ordinário, bem como a partir da mudança constitucional acima mencionada, o pouco prestígio conferido ao mencionado prazo de 81 dias deixou de existir de vez, até porque a contagem dos prazos se modificou com as novas fases do procedimento comum ordinário.

O que se encontra na jurisprudência são parâmetros para o julgamento em prazo razoável, especialmente, quando o acusado está submetido à prisão preventiva, levando, em caso de irrazoabilidade, a liberdade do acusado.

Os parâmetros para definição da razoabilidade do processo, estabelecidos pela Corte Interamericana de Direitos Humanos, foram sintetizados pelos autores ${ }^{26}$. Existe o parâmetro estabelecido em sete critérios e também em três. Esse último seria o mais aplicável, ou seja, a razoabilidade do prazo do processo seria definida com base nos seguintes critérios: 1) Complexidade do caso; 2) Atividade processual do imputado; 3) A conduta das autoridades judiciárias, somados ainda ao princípio da proporcionalidade.

Com isso, sendo a causa complexa ou contribuindo a defesa para a demora do processo ou mesmo em caso de excesso de processos sob a responsabilidade do juiz, essas circunstâncias poderiam levar a uma demora do processo.

\section{Da análise dos critérios atuais}

Ao analisar os critérios propostos, tem-se a indeterminação do conceito de complexidade, pois se os próprios substantivos já admitem uma ampla subjetividade do intérprete, imaginem-se os adjetivos. Ou seja, o que seria um processo complexo? Na jurisprudência,

PERADA A ALEGAÇÃO DE CONSTRANGIMENTO POR EXCESSO DE PRAZO. (Súmula 52, TERCEIRA SEÇÃO, julgado em 17/09/1992, DJ 24/09/1992 p. 16070). PRONUNCIADO O REU, FICA SUPERADA A ALEGAÇÃO DO CONSTRANGIMENTO ILEGAL DA PRISÃO POR EXCESSO DE PRAZO NA INSTRUÇÃO. (Súmula 21, TERCEIRA SEÇÃO, julgado em 06/12/1990, DJ 11/12/1990 p. 14873) NÃO CONSTITUI CONSTRANGIMENTO ILEGAL O EXCESSO DE PRAZO NA INSTRUÇÃO, PROVOCADO PELA DEFESA. (Súmula 64, TERCEIRA SEÇÃO, julgado em 03/12/1992, DJ 09/12/1992 p. 23482)

26 LOPES JUNIOR; Aury; BADARÓ, Gustavo Henrique. Direito ao processo penal no prazo razoável. Rio de Janeiro: Lúmen Júris, 2006. p. 40 
encontra-se como sinônimo de complexidade o processo com muitos réus, ou ampla necessidade de produção de provas. Como se pode ver, não há a mínima objetividade nesse parâmetro.

As dificuldades prosseguem no segundo critério, pois, segundo consta, a atividade probatória do réu poderia justificar a extensão do prazo de duração do processo, ou mesmo da prisão preventiva ou submissão a outras cautelares. Daí fica a questão: Como o réu pode ser punido pelo exercício de um direito constitucionalmente assegurado, no caso, a ampla defesa? Parece que a resposta a essa questão estaria no abuso do direito de defesa por parte do réu, mas que deveria estar comprovado nos autos.

Por fim, em relação ao excesso de demanda do poder judiciário, este seria um problema do Estado que, em tese, não poderia repercutir de maneira negativa para $\mathrm{o}$ réu, ainda mais como justificativa para a demora da prisão do réu.

Enfim, muito embora seja digno de elogio o esforço para a definição de critérios para a definição do prazo razoável, nota-se que estes ainda são excessivamente subjetivos para concretização da garantia constitucional da duração razoável do processo.

Feito esse registro a respeito dos critérios, deve-se agora avaliar quais seriam as repercussões da irrazoabilidade do prazo processual.

\section{Repercussões da prisão ou processo que não dura por prazo razoável}

Atualmente, não há no Direito Brasileiro qualquer mecanismo que determine a agilização de processo em curso há muito tempo. Aliás, não há definição nem mesmo de ordem de julgamento das demandas, ficando a cargo de cada magistrado estabelecer seus critérios para definir a ordem de julgamento.

Digno de elogio foi a medida adotada pelo Conselho Nacional de Justiça que na denominada Meta 2 sempre orienta os tribunais a efetuarem o julgamento de todos os processos distribuídos até determinado ano. No ano de 2009, a orientação era o julgamento dos processos distribuídos até 31.12.2005. Essa meta foi definida também para o ano de 2010 em relação aos processos distri- buídos até 31.12.2006 ${ }^{27}$. Todavia, há que se registrar que eventual descumprimento da referida meta somente levaria a uma improvável punição na esfera administrativa. Ou seja, não há um mecanismo conferido a parte para que leve o processo a ser julgado.

Um dos únicos efeitos da duração desarrazoada do processo estaria na extinção da punibilidade em razão da na prescrição, todavia, hoje, nota-se uma movimentação em relação à diminuição da aplicação das regras de prescrição, como: 1) A não admissão do da prescrição retroativa antecipada ${ }^{28}$;2) A vedação a prescrição retroativa tendo como termo inicial momento anterior à denúncia ${ }^{29}$; 3) A ampliação do prazo prescricional quando o crime tem pena máxima inferior a um $\operatorname{ano}^{30} \mathrm{e}$; 4) A nova contagem de prazo prescricional quando a vítima era menor ${ }^{31}$.

27 Quase 50\% da meta 2 de 2010 foi cumprida pelo Poder Judiciário. Isso significa que, até o final de fevereiro, foram julgados 546,7 mil processos ajuizados até 2006. Estabelecida em 2010, a meta 2 determina o julgamento de todos os processos de conhecimento distribuídos, em $1^{\circ}$ grau, $2^{\circ}$ grau e tribunais superiores, até 31 de dezembro de 2006 e, quanto aos processos trabalhistas, eleitorais, militares e da competência do tribunal do Júri, até 31 de dezembro de 2007. Para cumprir a meta, é preciso julgar mais $1,2 \mathrm{mi}-$ lhão de processos. Já a meta 2 de 2009 está em estágio bem mais avançado de cumprimento pelos tribunais brasileiros. A meta 2 de 2009, que determina o julgamento de todos os processos de conhecimento ajuizados até dezembro de 2005 , foi atingida em $71,5 \%$, o que significa que $3,2 \mathrm{mi}-$ lhões de processos nesta condição foram julgados.

28 É inadmissível a extinção da punibilidade pela prescrição da pretensão punitiva com fundamento em pena hipotética, independentemente da existência ou sorte do processo penal (Súmula 438, TERCEIRA SEÇÃO, julgado em 28/04/2010, DJe 13/05/2010).

29 Art. 110. $\$ 1^{\circ}$ A prescrição, depois da sentença condenatória com trânsito em julgado para a acusação ou depois de improvido seu recurso, regula-se pela pena aplicada, não podendo, em nenhuma hipótese, ter por termo inicial data anterior à da denúncia ou queixa (Redação dada pela Lei n ${ }^{\circ}$ 12.234, de 2010).

30 Art. 109. A prescrição, antes de transitar em julgado a sentença final, salvo o disposto no $₫ 1$ o do art. 110 deste Código, regula-se pelo máximo da pena privativa de liberdade cominada ao crime, verificando-se: (Redação dada pela Lei no 12.234, de 2010).VI - em 3 (três) anos, se o máximo da pena é inferior a 1 (um) ano. (Redação dada pela Lei no 12.234, de 2010).

31 Art. 111 - A prescrição, antes de transitar em julgado a sentença final, começa a correr: [...] V - nos crimes contra a dignidade sexual de crianças e adolescentes, previstos neste Código ou em legislação especial, da data em que a vítima completar 18 (dezoito) anos, salvo se a esse tempo já houver sido proposta a ação penal. 
Dentre as inovações relacionadas à prescrição, uma delas em especial confirma a prevalência do processo como aflição autônoma, como a vedação a prescrição pela pena virtual. Isso porque manter a persecução penal apenas pela possibilidade de alteração do prazo prescricional, tendo em vista a eventualidade de aparecimento de nova prova que altere a tipificação da conduta, é submeter o réu a processo que terá natureza de uma aflição autônoma. Afinal, sabe-se, de antemão, que aquela pretensão será alcançada pela prescrição.

Além da prescrição, deve-se registrar que a prisão processual que excede o prazo considerado razoável é considerada ilegal, e, com isso, pode levar a liberdade provisória do réu ${ }^{32}$.

Por outro lado, o réu absolvido, por sentença ou por revisão criminal, pode ajuizar ação de reparação de dano por erro judiciário, de difícil comprovação.

Deve-se registrar, por oportuno, que a Comissão de Juristas responsável pela elaboração de anteprojeto de Código de Processo Penal sugeriu prazos máximos para a prisão preventiva e que a definição de tais prazos foi aprovada pelo Senado Federal nos termos abaixo ${ }^{33}$ :

Art. 558. Quanto ao período máximo de duração da prisão preventiva, observar-se-ão, obrigatoriamente, os seguintes prazos:

I - 180 (cento e oitenta) dias, se decretada no curso da investigação ou antes da sentença condenatória recorrível, observado o disposto nos arts. 14, VIII e parágrafo único, e $31, \$ \$$ $3^{\circ}$ e $4^{\circ}$;

II - 360 (trezentos e sessenta) dias, se decretada ou prorrogada por ocasião da sentença condenatória recorrível, não se computando, no caso de prorrogação, o período anterior cumprido na forma do inciso I do caput deste artigo.

$\$ 1^{\circ}$ Não sendo decretada a prisão preventiva no momento da sentença condenatória recorrível de primeira instância, o tribunal poderá fazê-lo no exercício de sua competência recursal, hipótese em que deverá ser observado o prazo previsto no inciso II do caput deste artigo.

$\$ 2^{\circ}$ Acrescentam-se 180 (cento e oitenta) dias ao prazo previsto no inciso II do caput deste

32 Art. 5०. [...] LXV - a prisão ilegal será imediatamente relaxada pela autoridade judiciária;

33 BRASIL. Senado Federal. Disponível em: <http://www. senado.gov.br/atividade/materia/getPDF.asp?t=85509\&tp=1>. Acesso em: 08 jun. 2012. artigo, incluindo a hipótese do $₫ 1^{\circ}$, se houver interposição, pela defesa, dos recursos especial e/ou extraordinário.

$\$ 3^{\circ}$ Acrescentam-se, ainda, 60 (sessenta) dias aos prazos previstos nos incisos I e II do caput deste artigo, bem como nos $\$ \$ 1^{\circ}$ e $2^{\circ}$, no caso de investigação ou processo de crimes cujo limite máximo da pena privativa de liberdade cominada seja igual ou superior a 12 (doze) anos.

$\$ 4^{\circ}$ Nos processos de competência do Tribunal do Júri, o prazo a que se refere o inciso I do caput deste artigo terá como termo final a decisão de pronúncia, contando-se, a partir daí, mais 180 (cento e oitenta) dias até a sentença condenatória recorrível proferida pelo juiz.

Já em relação à definição do prazo processual, a proposta aprovada foi o denominado incidente de aceleração do processo:

Art. 274. Estando presentes as condições da ação e os pressupostos processuais, o juiz receberá a acusação e, não sendo o caso de absolvição sumária ou de extinção da punibilidade, designará dia e hora para a instrução ou seu início em audiência, a ser realizada no prazo máximo de 90 (noventa dias), determinando a intimação do órgão do Ministério Público, do defensor ou procurador e das testemunhas que deverão ser ouvidas.

$\$ 1^{\circ} \mathrm{O}$ acusado preso será requisitado para comparecer à audiência e demais atos processuais, devendo o poder público providenciar sua apresentação, ressalvado o disposto nos $\$ \$ 1^{\circ}$ e $2^{\circ}$ do art. 76.

$\$ 2^{\circ}$ Não cumprido o prazo previsto no caput deste artigo, o juiz poderá, de ofício ou a requerimento das partes, instaurar incidente de aceleração processual, determinando, se necessário, a prática de atos processuais em domingos, feriados, férias, recessos ou fora do horário de expediente forense, bem como nomear servidores ad hoc para a realização de atos específicos de comunicação processual e de expediente em geral.

$\$ 3^{\circ}$ A instauração do incidente será comunicada à presidência do tribunal competente, para as medidas administrativas cabíveis, inclusive a designação de magistrados em auxílio.

$\S 4^{\circ}$ As medidas previstas no $\$ 3^{\circ}$ deste artigo também serão comunicadas ao juízo deprecado e à presidência do respectivo tribunal, se for o caso.

Assim, tendo exposto o quadro normativo brasileiro, bem como as propostas em curso, nota-se que bem perto do Brasil, a solução foi um pouco mais ousada. Aury Lopes Júnior e Gustavo Badaró indicam o exemplo do Código 
de Processo Penal Paraguaio de 1998 que assim estabelece ${ }^{3435}$ :

Artículo 136. DURACION MAXIMA. Toda a persona tendrá derecho a uma resolución judicial definitiva em um plazo razonable. Por lo tanto, todo procedimiento tendrá uma duración máxima detrês años, contados desde el primer acto del procedimiento.

Este plazo sólo podrá se extender por seis meses más cuando exista uma sentencia condenatória, a fin de permitirla tramitación de los recursos.

La fuga ou rebeldia del inputado interrupirá el plazo de duración del procedimiento.

Cuando comparezca o sea capturado, se reiniciará el plazo.6 (grifo nosso)

Artículo 137. EFECTOS. Vencido el plazo previsto en el artículo anterior el juez o tribunal, de oficioo a petición de parte, declarará extinguida la acción penal, conforme a lo previsto por este código.

Cuando se declare la extinción de la acción penal por morosidad judicial, lá víctima deberá ser indeminizada por los funcionarios responsables y por el Estado. Se presumirá la negligencia de losfuncionários actuantes, salvo prueba em contrario. Em caso de insolvência del funcionário, responderá directamente el Estado, sin perjuicio de su direcho a repetir.

A par da discussão a respeito das mudanças legislativas, alguns juízes vem construindo outras repercussões para o processo que dura além do prazo razoável. Os autores já indicados informam certa movimentação dos tribunais, com vistas a garantir efetividade ao direito a julgamento em prazo razoável ${ }^{36}$.

34 É verdade que essa modificação ainda não foi capaz de resolver todos os problemas daquele país no tocante às prisões preventivas. Colhe-se, exemplificadamente, do relatório disponibilizado pela Corte Interamericana de Direitos Humanos: "A Comissão continua preocupada com a excessiva dilação da prisão preventiva daqueles que se encontram com processos anteriores a $1^{\circ}$ de março de 2000, baseados no Código de 1890. A lei $\mathrm{N}^{\circ} 1.444 / 99$, que regula o período de transição entre ambos sistemas, estabelece expressamente que as disposições do novo código a respeito da duração e garantias de revisão da prisão preventiva não são aplicáveis a estes casos, o que pode constituir uma violação do princípio de retroatividade da lei penal mais favorável ao réu, existindo vários casos de réus que já excederam os três anos de reclusão preventiva”. Disponível: http://www.cidh.oas.org/annualrep/2001 port/capitulo5a. htm acesso em 08 de junho de 2012.

35 LOPES JUNIOR.; Aury; BADARÓ, Gustavo Henrique. Direito ao processo penal no prazo razoável. Rio de Janeiro: Lúmen Júris, 2006.

36 LOPES JUNIOR.; Aury; BADARÓ, Gustavo Henrique. Direito ao processo penal no prazo razoável. Rio de Janeiro: Lúmen Júris, 2006. p. 40.
Ganha destaque a decisão do Tribunal de Justiça do Rio Grande do Sul, que atenuou a pena abaixo do mínimo legal, contrariando a Súmula 231 do STJ, no caso de réu que foi processado por mais de 8 anos, sem justificativa plausível, e que não voltara a reincidir. Na decisão ficou registrado que o processo penal tem caráter punitivo autônomo, sendo que se uma das finalidades da pena é justamente evitar a reiteração criminosa, esse objetivo já foi alcançado com a simples submissão do réu ao processo, ou seja, o processo já teria atendido às finalidades atribuídas a pena (art. 59, do CP).

Por outro lado, e no mesmo Tribunal de Justiça do Rio Grande do Sul, também se encontra precedente que simplesmente absolveu o acusado diante do excesso do prazo de julgamento ${ }^{37}$

Aury Lopes Júnior e Gustavo Badaró naquele texto originário, por sua vez, apontam algumas sugestões:

1) Deve ter mais atenção e incentivo à aplicação do perdão judicial (restrito aos art. 121, $\$ 5^{\circ}$ e $129, \$ 8^{\circ}$, do $C P$ ), vez que se o processo tem caráter punitivo, a própria aflição imposta pelo processo pode dispensar a pena, mas que tal aplicação vem sendo restringida a crimes de trânsito.

2) Deve-se viabilizar a indenização civil pela demora do processo e aplicação da atenuação da pena (aplicando-se a atenuante genérica do artigo 66, do CP).

3) Outra possibilidade aventada também seria o arquivamento do processo por desrespeito ao prazo processual adequado.

4) Já no tocante à punição do servidor envolvido pela prática de demora injustificada do processo, considerou-se muito tímida apenas a impossibilidade de promoção do juiz envolvido em demora injustificada do processo conforme estabelecido pela Constituição após a EC $45 / 2004$

\section{Da análise das propostas}

Quanto à ampliação das hipóteses de perdão judicial, deve-se recordar a dificuldade legal no tocante à aplicação da analogia para ampliar as hipóteses de cabimento do perdão judicial.

Ao que tudo indica, não se pode estender as hipó-

7 RIO GRANDE DO SUL. Tribunal de Justiça do Rio Grande do Sul, 6a C. - AP 70019476498 j. 14.06.2007. Rel. Nereu José Giacomolli. 
teses legais sem subverter o princípio constitucional da separação de poderes. Da mesma forma, as hipóteses de arquivamento do inquérito, bem como a extinção da punibilidade pelo excesso de prazo carecem de fundamento legal,sem a definição legal minimamente precisa de um tempo máximo de duração do processo.

Impedir a promoção dependerá de critérios para julgamento em prazo razoável e dificilmente se comprovará o nexo de causalidade específico.

Já no tocante à aplicação da atenuante genérica, entende-se que a sugestão pode ser perfeitamente aplicada a réus, mesmo condenados, que foram objeto de prazo desarrazoado de julgamento. Afinal, o artigo 66 do Código Penal ${ }^{38}$ confere ampla discricionariedade ao juiz, sendo o ideal que o descumprimento de prazo razoável do processo se torne causa de atenuação da pena.

\section{A título de contribuição}

À título de contribuição, nota-se uma grande dificuldade, ainda não superada pela doutrina ou mesmo pelo projeto de reforma do Código de Processo Pena, na definição de prazos peremptórios para a duração do processo, pois o incidente de agilização do processo previsto no projeto aprovado é muito tímido, estando ainda sujeito a uma série de condicionantes. É verdade, contudo, que, no tocante à prisão preventiva, a proposta aprovada estabelece um marco peremptório para o prazo ${ }^{39}$, todavia, não estabelece qualquer diferenciação entre o tipo de crime praticado e define o prazo máximo de prisão preventiva em 04 anos, o que é um exagero ${ }^{40}$.

Com base dessa constatação, ousa-se sugerir o seguinte:

a. Que sejam definidos parâmetros para o julgamento de quaisquer processos pelos juízes. Que a regra seja o julgamento de acordo com a ordem cronológica, mesmo que ressalvando a

3 Art. 66 - A pena poderá ser ainda atenuada em razão de circunstância relevante, anterior ou posterior ao crime, embora não prevista expressamente em lei.

39 Art. 560. Ao decretar ou prorrogar a prisão preventiva, o juiz indicará o prazo de duração da medida, findo o qual o preso será imediatamente posto em liberdade, observado o disposto nos $\$ \$ 1^{\circ}$ a $4^{\circ}$ deste artigo.

40 Art. 559. [...] $\$ 2^{\circ}$ Não obstante o disposto no $\$ 1^{\circ}$ deste artigo, em nenhuma hipótese a prisão preventiva ultrapassará o limite de 4 (quatro) anos, ainda que a contagem seja feita de forma descontínua. possibilidade de julgar medidas urgentes, como pedidos de liberdade provisória. Ou seja, julgar fora da ordem cronológica deveria ser a exceção, que deveria ser devidamente justificada.

\section{b. Além disso, sugere-se definir um prazo má-} ximo para um processo. A proposta que se faz no presente artigo é definir o prazo máximo do processo, limitando-o ao tempo máximo da pena do crime pelo qual está sendo processado, lapso normalmente menor que o da prescrição.

c. Descumprido o prazo máximo do processo, o réu seria beneficiado pela extinção da punibilidade, especialmente, se este solicitou o procedimento de agilização do processo abaixo explicitado.

d. Definido o prazo máximo do processo, caberia conferir às partes a possibilidade de solicitar a agilização do julgamento, uma espécie de preferência. Essa preferência seria baseada no prazo máximo previsto em lei para o procedimento, ou seja, após esse prazo as partes poderiam solicitar a agilização do julgamento, da mesma forma em que estabelecida no projeto aprovado do Código de Processo Penal, todavia, com a diferença de que há o prazo máximo para condução do processo.

e. Em cada uma das Varas e Tribunais, deveria haver a indicação de um fiscal que seria responsável pelo levantamento dos processos que estão fora do prazo e notificação do juiz/Desembargador/Ministro responsável pela condução do caso.

f. O prazo máximo definido deve levar em conta todas as instâncias, sendo que demora injustificada em quaisquer das instâncias deveria levar a possibilidade de responsabilização pessoal do servidor responsável pela fiscalização, caso não a faça de maneira correta, ou do Juiz que não atendeu a notificação do fiscal.

No caso de réu preso preventivamente, a proposta é a seguinte:

g. Como se sabe, o tempo que o réu fica preso pode ser objeto de detração caso seja ele definitivamente julgado. 
h. Por outro lado, não se tem na jurisprudência um prazo máximo para a manutenção da prisão preventiva e a proposta do Código de Processo Penal aprovada não faz diferença entre os crimes.

i. Sabe-se também que a prisão preventiva pode ser entendida como cumprimento provisório da pena, nos termos do entendimento sumulado do STF.

j. Ora, quais são os critérios para prender preventivamente? Inviabilidade de submissão a outro tipo de cautelar e o preenchimento dos requisitos fumus comissi delict e periculum libertatis, ou seja, prende-se para garantia do processo ou da coletividade em face da possibilidade de reiteração criminosa.

k. Estando preso e, se assim estivesse definitivamente, sabe-se que o réu teria direito à progressão de regime. E quais são os critérios para progressão de regime? Para progredir de regime, deve-se cumprir uma parte da pena e também demonstrar bom comportamento, ou seja, não se discute mais o que o réu fez para ser condenado e sim como está cumprindo a pena.

1. Dessa forma, um preso provisório não deve ter tratamento pior que o preso em definitivo, ou seja, o preso provisório não poderá ficar preso provisoriamente, o que na prática equivale ao regime fechado, por tempo superior àquele que ficaria se estivesse preso definitivamente.

m. Assim, a sugestão é: em caso de réu preso, este somente poderá ficar preso preventivamente durante o prazo que seria admitida a progressão de regime, baseada na pena mínima do crime ou da pena eventualmente já imposta. $\mathrm{Ou}$ seja, para a concessão da liberdade, não deveriam mais ser analisados os motivos da prisão preventiva e sim os pressupostos para a progressão de regime.

n.E por que a pena mínima? Ora, se a duração razoável do processo é uma obrigação do Estado, e se este descumpre sua atribuição, esse descumprimento deve favorecer o acusado.

o.E que teria a atribuição de solicitar a agilização do processo? Como esse direito é imposto ao direito, tanto defesa quanto acusação, o MP poderia suscitar a preferência de julgamento da mesma forma que o réu.

Veja que a proposta delineada neste estudo tem por base a definição de parâmetros baseados na pena do crime pelo qual o acusado está respondendo. Esses parâmetros foram construídos tendo em vista o princípio da proporcionalidade, pois para cada crime haverá um tempo de processo, sendo que para os processos mais graves com penas mais altas, o prazo considerado razoável será também maior.

\section{Considerações finais}

Em síntese, pode-se concluir que:

p. o sistema jurídico brasileiro recepcionou o direito de ser julgado num prazo razoável com o advento da EC n. 45/04 (que incorporou artigos da Convenção Americana de Direitos Humanos);

q. deve-se buscar o equilíbrio entre a aceleração antigarantista (processo-lebre) e a demora indevida (processo-tartaruga), pois ambos negam a jurisdição e esta exige qualidade, que só é alcançada com o equilíbrio do direito de ser julgado num prazo razoável.

r. Fixar um prazo máximo de duração de um processo, bem como de mecanismo que confira às partes a possibilidade de agilizar o processo, além de definir prazo máximo para a prisão do réu, certamente, conferirá maior estabilidade e segurança aos atores do processo.

s. De toda forma, a definição de um prazo máximo para o processo, bem como da possibilidade de solicitar a sua agilização dependeria de alteração legislativa. Todavia, no tocante à definição do prazo máximo para o réu estar preso, essa necessidade não existiria, pois bastaria considerar o réu preso provisoriamente como se preso em definitivo estivesse, pois, convenha-se, quanto à restrição da liberdade, não há diferença entre prisão provisória e definitiva. 


\section{Referências}

ABBAGNANO, Nicola. Dicionário de filosofia. ed. rev. e ampl.. São Paulo: M. Fontes, 2007.

LOPES JUNIOR, Aury; BADARÓ, Gustavo Henrique. Direito ao processo penal no prazo razoável. Rio de Janeiro: Lúmen Júris, 2006. 